\title{
GAMBARAN KADAR MAGNESIUM SERUM PADA ORANG LANJUT USIA DENGAN UMUR 60-74 TAHUN
}

\author{
${ }^{1}$ Clara V. Malingkas \\ ${ }^{2}$ Michaela E. Paruntu \\ ${ }^{3}$ Youla A. Assa
}

\author{
${ }^{1}$ Kandidatr Skripsi Fakulras Kedokteran Universitas Sam Ratulangi Manado \\ ${ }^{2}$ Bagian Biokimia Fakultas Kedokteran Universitas Sam Ratulangi Manado \\ Email: cmalingkas11_089@yahoo.co.id
}

\begin{abstract}
Magnesium is the fourth most important cation inside human's body after sodium, calcium, and potassium. Magnesium's roles in the body are carbohydrate, lipid, and protein metabolism and in mitochondrial ATP synthesis. Approximately 300 enzymes are activated by magnesium, including glycolysis, oxidative metabolism, as well as potassium and calcium transmembrane transport. In elderly, magnesium serum levels depend on daily food intake, the present illness, and medicine usage. This study was conducted to view magnesium serum levels in elderly aged 60-74 years old. This study was a descriptive study with cross-sectional design. Twenty six individuals were chosen as samples using total sampling method. The result showed that the average magnesium serum levels was 2,005 with 24 samples have a normal magnesium serum levels within the range of 1,70-2,43 $\mathrm{mg} / \mathrm{dL}$, two samples have magnesium serum levels $<1,70 \mathrm{mg} / \mathrm{dL}$, and there's no sample with magnesium serum levels $>2,43 \mathrm{mg} / \mathrm{dL}$. Based on the analysis result, it can be concluded that there is normal magnesium serum levels in 24 samples, hypomagnesaemia in two samples and there is no sample with hypermagnesaemia.
\end{abstract}

Keywords: Magnesium serum levels, elderly.

\begin{abstract}
Abstrak: Magnesium merupakan kation keempat yang terpenting di dalam tubuh setelah natrium, kalsium, dan kalium. Fungsi magnesium antara lain pada metabolisme karbohidrat, lipid dan protein serta sintesis ATP mitokondria. Sekitar 300 enzim diaktivasi oleh magnesium, termasuk glikolisis, metabolisme oksidatif, serta transpor transmembran kalium dan kalsium. Pada orang lanjut usia, kadar magnesium serum tergantung dari asupan makanan sehari-hari, penyakit yang diderita, dan penggunaan obat-obatan. Penelitian ini dilakukan untuk mengetahui gambaran kadar magnesium serum pada orang lanjut usia dengan rentang usia 60-74 tahun (elderly). Penelitian ini merupakan penelitian deskriptif dengan desain crosssectional. Sampel dalam penelitian ini berjumlah 26 orang yang diambil menggunakan metode total sampling. Hasil analisis menunjukkan 24 sampel memiliki kadar magnesium serum normal dengan rentang 1,70-2,43 mg/dL, dua sampel dengan kadar magnesium serum $<1,70$ $\mathrm{mg} / \mathrm{dL}$, dan tidak ada sampel dengan kadar magnesium serum $>2,34 \mathrm{mg} / \mathrm{dL}$. Berdasarkan hasil analisis dapat disimpulkan bahwa terdapat gambaran kadar magnesium serum normal pada 24 sampel, hipomagnesemia pada 2 sampel dan tidak ada gambaran hipermagnesemia pada sampel.
\end{abstract}

Kata kunci: Kadar magnesium serum, orang lanjut usia.

Di masa sekarang ini jumlah orang lanjut usia terus meningkat, maka perlu dilakukan usaha untuk memberikan kesejahteraan kehidupan penduduk usia lanjut. Pada tahun 2000 jumlah orang lanjut usia diproyeksikan sebesar 7,28 \% dan pada tahun 2020 sebesar 11,34\% dari total penduduk. Dari data USA-Bureau of 
the Census, antara tahun 1990-2025, diperkirakan Indonesia akan mengalami pertambahan warga lansia terbesar seluruh dunia. ${ }^{1}$ Perkiraan resmi menunjukkan bahwa jumlah penduduk lanjut usia (lansia) usia 65 tahun dan lebih mulai meningkat secara fantastis, dari 296 juta (1980) menjadi 403 juta (2000) dan akan meningkat lagi menjadi 649 juta pada tahun $2020 .^{2}$

Sekitar 300 enzim diaktivasi oleh magnesium, dan kebanyakan aspek biokimia intraseluler bergantung pada magnesium, termasuk glikolisis, metabolisme oksidatif, serta transpor transmembran kalium dan kalsium. ${ }^{3}$ Magnesium juga dibutuhkan untuk transpor ion-ion lainnya seperti kalium dan kalsium dan dilibatkan dalam sintesis protein, khususnya pada pembentukan cyclic adenosine monophosphate (cAMP). Magnesium bekerja pada sistem neuromuskuler dengan menstabilisasikan akson saraf, juga mempengaruhi pelepasan neurotransmiter di sambungan mioneural. ${ }^{4}$

Pada lansia, ketidakseimbangan cairan dan elektrolit sering disebabkan oleh masalah jantung dan gangguan ginjal. Aktivitas juga sangat berpengaruh terhadap kebutuhan cairan dan elektrolit. Aktivitas menyebabkan peningkatan proses metabolisme di dalam tubuh. Hal ini mengakibatkan peningkatan pengeluaran cairan melalui keringat, dengan demikian jumlah cairan yang dibutuhkan juga meningkat. ${ }^{5}$

Kadar normal magnesium yaitu diantara 1,70 - 2,43 mg/dL. ${ }^{6}$ Gangguan akibat hipomagnesemia termasuk gangguan neuromuskuler, gastrointestinal, dan perubahan kepribadian. Gangguan neuromuskuler termasuk tanda Trousseau dan tanda Chvostek yang positif, spasme otot spontan menyeluruh, tremor, anoreksia, mual dan muntah. ${ }^{4}$ Gangguan akibat hipermagnesemia yaitu somnolen dan hipotensi, dan elektrokardiogram dapat menunjukkan perpanjangan dari interval PR dan durasi QRS dengan memuncaknya gelombang $\mathrm{T}^{7}$

Gangguan keseimbangan magnesium pada lanjut usia, dapat terabaikan karena konsentrasi magnesium serum tidak diukur secara rutin. Gangguan gastrointestinal dengan malabsorpsi dan diare, serta alkoholisme merupakan keadaan yang mengakibatkan ketidakseimbangan magnesium yang sering ditemui pada orang lanjut usia. ${ }^{7}$ Data dari National Health and Nutrition Examination Survey (NHANES) III menemukan bahwa asupan harian magnesium semakin menurun sesuai usia tanpa memandang jenis kelamin dan ras. Analisis dari survey NHANES III yang sama menunjukkan bahwa asupan magnesium pada populasi lanjut usia di Amerika Serikat jauh di bawah kebutuhan harian yang direkomendasikan. ${ }^{8}$

\section{METODE PENELITIAN}

Penelitian ini merupakan penelitian deskriptif dengan desain penelitian crosssectional (potong lintang). Sampel penelitian yaitu penduduk lanjut usia tahun di Balai Penyantunan Lanjut Usia (BPLU) “Senja Cerah" yang berusia 60-74. Sampel diambil dengan metode total sampling dan berjumlah 26 orang. Kadar magnesium serum yang akan diperiksa diambil dari darah vena. Penelitian telah dilaksanakan pada bulan Agustus 2014 sampai Januari 2015. Variabel penelitian yaitu kadar magnesium serum, dan orang lanjut usia.

\section{HASIL PENELITIAN}

Sebagian besar responden berjenis kelamin perempuan sebanyak $57,7 \%$ atau berjumlah 15 orang sedangkan responden laki-laki sebanyak 42,3\% atau berjumlah 11 orang. Berdasarkan umur, didapatkan nilai rata-rata 69,11 , median 70,5 , dan modus 71. Standar deviasi adalah 4,13. Nilai minimum yaitu 60 dan nilai maksimum yaitu 74 .

Berdasarkan kadar magnesium serum didapatkan nilai rata-rata 2,005, median 2,015, dan modus 2,25. Standar deviasi adalah 0,22. Nilai minimum data yaitu 1,50 dan nilai maksimum 2,37. Berdasarkan pengelompokan kadar magnesium serum dibagi menjadi tiga kelompok yaitu kelompok hipomagnesemia, normal, dan 
hipermagnesemia. Dari 26 responden didapatkan 92,31\% atau berjumlah 24 orang termasuk kelompok normal, 7,69\% atau berjumlah dua orang termasuk kelompok hipomagnesemia, dan tidak ada yang termasuk kelompok hipermagnesemia.

\section{BAHASAN}

Dari 26 orang responden, didapatkan dua orang atau $7,69 \%$ mengalami penurunan kadar magnesium atau hipomagnesemia yang kadar magnesiumnya $<1,7 \quad \mathrm{mg} / \mathrm{dL}$. Hal ini berhubungan dengan prevalensi terjadinya hipomagnesemia yaitu pada populasi dengan keadaan sakit yang serius (rawat inap, perawatan intensif, rawat intensif pediatri), pertambahan usia (tua / tinggal di panti jompo), atau penyakit yang spesifik lainnya. ${ }^{9}$

Dari dua responden dengan hipomagnesemia ini, satu diantaranya menderita hipertensi dan yang lainnya menderita diabetes mellitus yang tidak dikontrol. Hal ini mungkin yang menyebabkan kadar magnesium kurang. Hasil dari penelitian cross-sectional Atherosclerosis Risk in Communities (ARIC) menunjukkan hubungan yang negatif antara asupan magnesium dan kadar magnesium serum dengan tekanan sistolik dan diastolik. Penelitian klinis menunjukkan beberapa bentuk hipomagnesemia pada pasien hipertensi memiliki hubungan terbalik yang signifikan antara kadar magnesium dan tekanan darah. $^{10}$ Hipomagnesemia pada pasien diabetes biasanya diamati pada pasien yang kontrol metaboliknya kurang, atau berhubungan dengan komplikasi kronik diabetes mellitus. Mekanisme defisiensi magnesium pada pasien diabetes masih belum jelas, tetapi diabetes dipertimbangkan sebagai faktor pencetus peningkatan ekskresi magnesium melalui urin. ${ }^{11}$ Penelitian di Universitas Columbia, New York, melaporkan bahwa sebanyak satu dari tiga penderita diabetes bisa mengalami hipomagnesemia. ${ }^{12}$

Beberapa penyakit ada yang berkaitan dengan tingginya kejadian hipomagnesemia diantaranya penyakit kardiovaskuler (hipertensi, gagal jantung kongestif, penyakit jantung koroner), diabetes, diare, penggunaan obat diuretik, hipokalemia, hipokalsemia, dan malabsorpsi. ${ }^{9}$ Selain hal-hal yang telah disebutkan di atas, hipomagnesemia pada penelitian ini mungkin dapat disebabkan akibat asupan magnesium yang tidak memadai dalam makanan sehari-hari. ${ }^{4,13}$

Sebanyak 24 responden pada penelitian ini memiliki kisaran kadar magnesium serum yang normal. Hal-hal ini dipengaruhi oleh asupan makanan, kebiasaan makan dan minum, penyakit yang diderita, dan konsumsi obat-obatan. ${ }^{9}$

\section{SIMPULAN}

Berdasarkan data hasil penelitian yang telah dilakukan, maka ditarik kesimpulan dari 26 sampel yang diteliti, sebagian besar atau sebanyak 92,3\% memiliki gambaran kadar magnesium serum dalam batas normal yaitu diantara 1,70-1,43 mg/dL.

\section{SARAN}

Berdasarkan kesimpulan yang telah dibuat, maka saran-saran yang dapat disampaikan ialah sebagai berikut:

1. Untuk sampel dengan hipomagnesemia disarankan untuk melakukan pemeriksaan kadar magnesium kembali, dan jika berhubungan dengan penyakit yang diderita sebaiknya dilakukan pengendalian dan pengobatan terhadap penyakit yang diderita.

2. Perlu dilakukan penelitian dengan sampel yang lebih banyak dan sesuai dengan metode pengambilan sampel.

3. Perlu dilakukan penelitian dengan menggunakan variabel yang lebih banyak, misalnya penyakit penyerta pada sampel.

\section{DAFTAR PUSTAKA}

1. Boedhi-Darmojo R. Martono HH, Pranarka, K, editor. Buku ajar geriatri (ilmu kesehatan usia lanjut). Edisi ke4. Jakarta: Balai penerbit FKUI; 
2011.h.-31.

2. Prayitno S. Penduduk lanjut usia : suatu tinjauan teori, masalah, dan implikasi kebijakan. Masyarakat, kebudayaan, dan politik. 1999;4:45.

3. Gaw A, Murphy MJ, Cowan RA, O’Reilly DS, Stewart MJ, Shepherd J. Fosfat dan Magnesium. Dalam: Salim N, Yesdelita N, editor. Biokimia Klinis. Edisi ke-4. Jakarta. EGC; 2012.

4. Gibson RS. Principles of nutritional assessment. $\quad 2^{\text {nd }}$ edition. New Zealand: Oxford; 2005.h.661-74.

5. Mardella EA. Klien gangguan keseimbangan cairan dan elektrolit. Dalam: Tamsuri A. Cairan dan elektrolit dalam tubuh manusia. Jakarta: EGC; 2004.p.6-7.

6. Konrad M, Schlingmann KP. Magnesium. In: Stipanuk M, editor. Biochemical, physiological, molecular aspect of human nutrition. $2^{\text {nd }} \quad$ edition. Philadelphia: Elsevier;2006.p.922-33.

7. Lindeman RD. Mineral Requirements. In: Chernoff $\mathrm{R}$, editor. Geriatric nutrition. $3^{\text {rd }}$ edition. Massachusetts: Jones and Bartlett Publishers; 2006.p.90-2.

8. Barbagallo $M$, Belvedere $M$, Dominguez L. Magnesium homeostasis and aging. Magnesium research. 2009;22:238.

9. Mouw DR, Latessa RA, Sullo EJ. What are the cause of hypomagnesemia?. The journal of family practice.2005;54(02):156-78.

10. Sontia B, Touyz RM. Role of magnesium in hypertension. 28 March 2006 [cited 22 January 2015]. Available from: www.magnezyum.info/images/hipert ansyon_4.pdf.

11. Sales CH, Pedrosa LFC. Magnesium and diabetes mellitus: their relation. Clinical nutrition.2006;25:557.

12. Tosielo, Lorraine. Hypomagnesemia and diabetes mellitus. Archives of internal medicine. 1996;156:1143-48.

13. Almatsier S. Prinsip dasar ilmu gizi. Jakarta: Gramedia pustaka utama; 2005.h.246-48. 